\title{
MEMBANGUN KARAKTER PADA ANAK USIA PRASEKOLAH
}

\author{
Bambang Syamsul Arifin
}

Fakultas Psikologi Universitas Islam Bandung

Preschool children - as we have known - have much potential which could be used as a basis to build up their character, either in family, school, and society. Their potential therefore needs to be nurtured to help them to achieve their potential to the fullest. But daily life nowadays-could bring negative impact on their development. The intensity of meaningful communication in daily conversation between children and their parents - was seen as a major obstacle on this process, which then becoming the main reason behind the unsuccessful learning of moral values, honesty, and manners. This condition then have negative impact on their character-as we have seen today-many children has emotional disturbance, violent, and shows an inappropriate behaviors.

From this phenomenon, a couple effective approaches could be used to design an effective learning good program for their character development-which are knowing the good, reasoning the good, feeling the good, and acting the good. From this approaches point of view-altering their behavior and make good manners as habit were seen as the best approaches available, since altering behavior can be very effective way to develop their character and potential to the fullest. Their character behavior would also be affected by the daily basis learning and natural conditioning to make a good behavior as a habit.

Character development for children in this case are including personal character which is an accumulation of goodness that will drive individuals to do the right thing, have a strong self consciousness on moral values, become a good member of society, ethical, knows which is right and wrong, and act consistently on Golden Rules. Aside from it, nationhood and citizenship characteristic is need to be developed too-where this trait is the accumulation of the personal goodness and set of moral and culture values such as an obedience to the state authority, laws, responsibility, fairness and active participation on public affairs.

Keywords: character, values, manners and good behaviors

\section{Pendahuluan}

Anak usia prasekolah merupakan bagian dari unsur bangsa yang mempunyai hak untuk mendapatkan kesempatan pendidikan yang baik sebagai bekal dalam mengarungi kehidupan berbangsa dan bernegara. Potensi otak anak seperti the absorbent mind. Sehingga pada masa ini anak cepat sekali meniru perilaku orang dewasa. Para ahli psikologi menganalogikan otak anak dengan sponge. Sponge yang kering cepat sekali menyerap air. Apabila sponge diletakkan ke dalam air yang jernih dan bersih, yang diserap juga air jernih dan bersih. Namun sebaliknya, apabila sponge diletakkan ke dalam air selokan yang kotor, yang diserap juga air selokan yang kotor. Artinya anak sangat peka dalam menerima stimulus yang diberikan oleh orang dewasa dan lingkungannya. Sehingga orang tua dan guru yang mengajar kebaikan kepada anak usia dini lebih efektif. Air jernih yang bersih sebagai gambaran kebaikan yang diberikan oleh orang tua dan guru kepada anak berdampak dalam otak anak, adalah kejernihan, kebersihan atau kebaikan, sedangkan apabila orang tua dan guru menyampaikan sesuatu 
pelajaran yang kurang baik, maka dampak yang terjadi di dalam otak anak adalah kurang baik atau buruk.

Pada umumnya usia anak pada periode ini, yaitu antara empat sampai dengan enam tahun. Sebagian mereka pada usia ini sedang mengikuti pendidikan di Taman Kanak-Kanak, Raudlatul Athfal atau pendidikan anak usia prasekolah. Orang tua dan guru membekali mereka dengan pengalaman yang handal dalam menghadapi ragam peluang, rintangan, tantangan, dan bahaya yang tidak pernah dialami oleh orang tua, guru, dan generasi pendahulunya. Bahkan anak-anak mendapatkan suguhan informasi yang tidak relevan dengan nilai-nilai dan budaya bangsa yang dimilikinya melalui media masa dan sumber eksternal lain dalam budaya kekinian yang dianggap lebih maju dan modern.

Sehubungan dengan hal ini, Wisnubrata Hendrojuwono (2008) menyampaikan hasil penelitan yang dilakukan oleh American Family Research Council (1990) dan Harver (1999) tentang keluarga di Amerika Serikat. Hasil penelitian yang diperoleh menunjukkan, bahwa anak-anak menghabiskan waktu 38,5 menit perminggu atau 33,4 jam per tahun untuk melakukan pembicaraan bermakna dengan orang tuanya, padahal mereka menghabiskan waktu 1.500 jam untuk menonton televisi. Keadaan ini memberikan gambaran, bahwa kesempatan penyemaian karakter yang baik dalam lingkungan keluarga memimiliki waktu yang sangat singkat dan terbatas. Artinya peluang untuk menerima informasi dan pengaruh eksternal yang sarat dengan muatan nilai-nilai budaya dan etika-moral dari luar sangat dominan bila dibandingkan dengan peluang waktu yang digunakan untuk penanaman karakter yang baik sekalipun dalam lingkungan keluarga yang sangat dekat dengan anak.

Sementara itu, sering terjadi anak-anak yang menampakkan perilaku yang kurang baik. Sebagian mereka berkata-kata kasar, penuh kekerasan, mudah terbakar amarahnya, sehingga terjadi perselisihan, bahkan perkelahian diantara mereka. Di samping itu, Keprihatinan yang dirasakan oleh bangsa Indonesia saat ini yaitu kecenderungan munculnya para penganut budaya instant yang menjalar dalam berbagai aspek kehidupan. Gejala ini tampak dalam segala harapan dan cita-cita ingin diraih dengan waktu cepat tanpa dimbangi oleh upaya-upaya yang memadai dan sebanding dengan hasil yang dicapainya. Padahal dalam meraih sesuatu tujuan yang telah ditentukan hendaknya dibarengi dengan usaha-usaha dan kerja keras, serta pikiran yang cerdas. Hal ini sesuai dengan pepatah yang popular dalam masyarakat Indonesia, yaitu: "berakit-rakit ke hulu, berenang-renang ke tepian". Di samping itu, kehancuran suatu bangsa dapat terjadi apabila bangsa tersebut telah kehingan jati dirinya yang sedianya melekat dalam diri setiap individu.

Pembangunan karakter bangsa yang semula lebih berbasis nilai-nilai ajaran Islam, pada masa orde baru beralih kepada Pendidikan Moral Pancasila. Kemudian proses internalisasi nilai-nilai yang terkandung dalam Pendidikan Moral Pancasila dijabarkan melalui 
kegiatan penghayatan dan pengamalan Pancasila bagi seluruh lapisan masyarakat Indonesia. Penataran-penataran mengenai Pedoman Penghayatan dan Pengamalan Pancasila dilakukan kepada masyarakat. Setiap instansi dan penyelenggara pendidikan mulai dari tingkat menengah sampai ke perguruan tinggi. Program ini lebih merupakan indoktrinasi, bukan melalui proses pencerahan. Sejak saat itu bangsa Indonesia kehilangan ajaran budi pekerti yang luhur yang sebagian besar telah diwarnai oleh nilai nilai akhlak karimah yang diajarkan oleh agama Islam yang sempurna.

Pembangunan karakter berlaku bagi seluruh lapisan masyarakat dan bangsa baik anak-anak, kaum muda, juga para orang tua. Tulisan ini memfokuskan pembangunan karakter pada anak usia prasekolah. Usia ini mejadi pilihan karena saat yang paling tepat untuk melakukan penyemaian nilai-nilai dasar manusia dan etika-moral yang luhur sesuai dengan tahapan dan tugas perkembangannya. Nilai dasar yang paling utama disemaikan kepada usia ini, yaitu kejujuran, tanggung jawab, kebaikan hati, kemurahan hati, keteguhan hati, kebebasan, kesetaraan, dan sikap respek terhadap fenomena yang terjadi di sekitarnya.

\section{Pembahasan}

Istilah karakter berasal dari bahasa Yunani yang berarti "to mark", pengertian ini lebih terfokus pada melihat tindakan atau perilaku seseorang. Karakter juga menurut Wynne (dalam Ratna Megawangi, 2008) memiliki arti bagaimana seseorang menujukkan tingkah laku. Bila seseorang berperilaku tidak jujur, kejam, sombong, angkuh, rakus, dan tamak, maka orang tersebut telah memanifestasikan perilaku yang buruk dalam kehidupannya. Namun sebaliknya, apabila seseorang berperilaku selalu jujur, suka menolong orang lain, dermawan, baik sangka, menghormati orang lain, dan rendah hati maka orang tersebut memanifestakan perilaku yang baik dan mulia. Karakter dalam Webster Encyclopedia Unabridged Dictionary (1989) yaitu "The aggregate of features and traits that form the apparent individual native of some person or thing-moral or ethical qualityquality of honesty, courage, or the likeintegrity-reputation-good repute.

Sementara itu, Batasan karakter menurut Reber, (1985), adalah the sum of total or integration of all such marking (traits) to yield unified whole which reveals the nature (the "character") of a situation, of an even or a person. Pengertian karakter yang lebih sederhana dikemukakan oleh Lickona, (dalam Wisnubrata Hendrojuwono, 2008) bahwa "Character is often defined as doing the right thing when no one is looking". Lebih lanjut Wisnubrata mengemukakan, bahwa "Karakter terkait dengan integritas dan merupakan kualitas manusia yang berkaitan dengan etikamoral, kejujuran, dan keberanian untuk menolak hal-hal yang melanggar etika-moral dan kejujuran. Dalam hal etika-moral dan kejujuran berlaku prinsip all on none, artinya tidak mengenal daerah abu-abu".

Dengan demikian, dapat dikatakan, bahwa karakter merupakan manifestasi kua- 
litas manusia yang menggambarkan keterkaitan antara tingkah laku dengan ketaatannya terhadap nilai-nilai, ajaran agama, budaya, etika-moral, kejujuran dan keberanian menegakkan kebenaran. Seseorang yang berpegang teguh terhadap nilai-nilai agama, budaya, etika-moral dan keberanian menegakkan kebenaran seperti jujur, rendah hati, dan menolong orang yang mengalami kesulitan disebut orang yang memiliki karakter mulia. Namun sebaliknya, apabila seseorang tidak berpegang pada nilai-nilai, etika-moral, seperti tidak jujur, suka berdusta, angkuh dan sombong maka orang seperti ini tergolong kepada orang-orang yang memiliki karakter buruk.

\section{Arti Penting Pembangunan Karakter pada} Anak Usia Prasekolah

Pembangunan karakter bangsa Indonesia telah dilakukan oleh para tokoh dan para pahlawan bangsa sejak jaman dahulu kala. Raden Ajeng Kartini salah seorang tokoh yang memperjuangkan kesetaraan kaum wanita dengan kaum pria misalnya, pada awal tahun 1900 mengungkapkan dalam suratnya yang disampaikan kepada Ny. Ovink" Bilamana pemerintah sungguh-sungguh ingin memajukan peradaban, maka pendidikan ilmu dan pendidikan budi pekerti harus dilakukan secara bersama-sama”. Sedangkan isi surat yang dikirimkan kepada Ny. Abendanon pada awal tahun 1901, beliau menyatakan, bahwa "Bagi saya pendidikan itu berarti pembentukan watak dan akal pikiran". Ungkapan ini menunjukkan betapa pentingnya penyampaian ilmu pengetahuan dan penanaman budi pekerti sebagai pondasi dalam pembangunan karakter dan bagi kemajuan bangsa.

Demikian halnya dengan ungkapan yang dikemukakan oleh K. H. Ahmad Dahlan, bahwa "Dalam penegembangan karakter berpedoman kepada 'amar ma'ruf nahi munkar melalui ajaran agama Islam". Dalam hal ini amar ma'ruf nahi munkar merupakan benteng pertahanan bagi pemeliharaan dan penanaman akhlak karimah kepada anak-anak dan umat Islam umumnya. Tokoh lain yang memiliki komitmen kebangsaan yang tinggi, yaitu $\mathrm{Ki}$ Hajar Dewantara menggunakan pendekatan kebudayaan dan kesenian dalam pengembangan karakter bangsa kepada anak-anak. Budaya dan kesenian menjadi penopang utama dalam pembentukan karakter anak-anak.

Pembangunan karakter merupakan salah satu solusi yang strategis dalam meningkatkan kualitas kehidupan Bangsa. Kemajuan suatu bangsa dapat dicapai oleh bangsa yang memiliki karakter yang berkualitas tinggi. Misalnya bangsa Jepang memiliki ketaatan yang kuat terhadap nilai-nilai budaya yang menjadi karakter bagi seluruh warganya. Demikian halnya dengan individu yang berkarakter mulia dapat berjalan menuju kehidupan yang lebih baik dan maju, karena memiliki pegangan yang kokoh terhadap nilai, etikamoral, kejujuran dan keberanian untuk melakukan kebenaran. Hal ini menggambarkan kebajikan pribadi yang mulia.

Uraian tersebut di atas menggambarkan betapa pentingnya membangun karakter kepada anak usia prasekolah khususnya bagi 
perkembangan dan kemajuan hidup seseorang dan masyarakat. Bahkan bagi kelangsungan, kebesaran, dan kemajuan suatu bangsa. Bangsa yang memiliki karakter yang baik akan mendapatkan kemudahan dalam mencapai kesejahteraan, kemakmuran, kemandirian, kemajuan, dan akan terhindar dari kerusakan dan penyimpangan yang dilakukan oleh warganya.

\section{Klasifikasi Karakter Manusia}

Karakter yang memiliki kualitas baik akan berkembang sepanjang waktu melalui proses pembelajaran, pemberian contoh yang baik, keteladanan, dan melaksanakannya tanpa secara terus-menerus tanpa henti, bahkan sampai akhir hayat. Dengan kata lain, bahwa pembentukan karakter pada seseorang melalui proses pendidikan yang berlangsung lama atau seumur hidup. Upaya membangun karakter yang baik dilakukan secara terus-menerus dan berkesinambungan tanpa batas usia. Semakin lama seseorang membangun karakter yang baik, akan semakin baik pula kualitas karakternya yang ditampilakn dalam perilaku kehidupan sehari-harinya.

Nilai yang baik menurut Wisnubrata meliputi tiga bagian nilai objektif, yaitu pengetahuan moral, perasaan moral, dan perilaku moral. Dengan kata lain, bila individu mengetahui hal-hal yang baik, akan mendambakan yang baik dan kemudian berbuat yang baik. Orang yang melakukan kebaikan dilatarbelakangi oleh pengetahuan dan perasaan kebaikan. Bagi orang yang mengetahui dan perasaan keburukan memiliki kecenderungan untuk berbuat keburukan. Perilaku yang baik dan buruk yang menjadi kebiasaan dan melekat dalam diri seseorang menjadi karakter. Sehubungan dengan hal ini, sering terjadi sebutan kepada seseorang memiliki karakter yang baik atau berkarakter buruk. Karakter yang baik seseorang disebut dua sisi karakter yang melekat dalam diri individu, yaitu:

1. Karakter pribadi, yaitu merupakan akumulasi kebajikan yang mempengaruhi individu untuk melakukan yang benar, menyadari pentingnya moral, menjadi orang baik, etikal, tahu mana yang benar dan mana yang salah, bertindak konsisten sesuai Golden Rules.

2. Karakter kewarganegaraan, yaitu merupakan kebajikan yang meliputi kebajikan pribadi dan nilai-nilai, seperti menghormati nilai dan otorita, bertanggung jawab, berlaku adil, berkeadilan, dan berpartisipasi dalam urusan kemasyarakatan.

Uraian tersebut mengklasifikasikan karakter seseorang pada dua karakter yang merupakan satu kesatuan dan tidak dapat dipisahkan. Kedua karakter yang melekat dalam diri seseorang tersebut, menunjukkan akumulasi kebajikan pribadi dan kebajikan kewarganegaraan. Artinya seseorang yang memiliki karakter yang baik senantiasa melakukan yang benar, menyadari pentingnya moral, menjadi orang baik, etikal, tahu mana yang benar dan mana yang salah, bertindak konsisten sesuai Golden Rules. Di samping itu, seseorang tersebut memiliki kebajikan pribadi dan nilai-nilai, seperti menghormati nilai-nilai dan otorita, bertanggung jawab, berlaku adil, 
berkeadilan, dan berpartisipasi aktif dalam urusan kemasyarakatan.

Peterson dan Seligman (dalam Wisnubrata, 2008) mengungkapkan enam core virtues yang dapat dicapai melalui sekelompok kekuatan karakter (character strengths). Keenam core virtues ini, meliputi: Wisdom and knowledge (kearifan dan pengetahuan), Courage (keteguhan hati), Humanity (kemanusiaan), Justice (keadilan), Temperance (pengendalian diri), dan Transenden (transenden).

1. Wisdom and knowledge (kearifan dan pengetahuan), merupakan kebajikan utama melalui kreativitas, rasa ingin tahu, keterbukaan pikiran, senang belajar, dan perspektif.

2. Courage (keteguhan hati), melalui keberanian dalam menempuh bahaya, persisten, integritas, dan vitalitas.

3. Humanity (kemanusiaan), merupakan kebajikan utama melalui kasih, cinta, kebaikan hati, dan intelegensi social.

4. Justice (keadilan), merupakan kekuatan karakter yang meliputi kewargaan, rasa keadilan, dan kepemimpinan.

5. Temperance (pengendalian diri), merupakan kebajikan utama yang meliputi sikap memaafkan kepada orang lain dan murah hati, rendah hati, sopan, santun, prudent, dan mengatur diri.

6. Transenden (transenden), merupakan kebajikan utama yang meliputi menghargai keindahan dan keunggulan, bersyukur, harapan, humor, dan spiritualitas.

Secara global klasifikasi karakter manusia meliputi: karakter pribadi, yang merupa- kan akumulasi kebajikan yang mempengaruhi individu untuk melakukan yang benar, menyadari pentingnya moral, menjadi orang baik, etikal, tahu mana yang benar dan mana yang salah, bertindak konsisten sesuai Golden Rules. Karakter kewarganegaraan, yaitu mengenai kebajikan pribadi dan nilai-nilai, seperti menghormati nilai dan otorita, bertanggung jawab, beraku adil, berkeadilan, dan berpartisipasi dalam berbagai urusan kemasyarakatan.

\section{Upaya Membangun Karakter pada Anak Usia Prasekolah}

Setiap orang tua dan guru ingin membina anaknya agar menjadi orang yang baik, mempunyai kepribadian yang kuat, sikap mental yang sehat, dan akhlak yang terpuji. Sehubungan dengan hal ini, Bambang Samsul Arifin (2008) mengemukakan, bahwa pembinaan tampak tidak mudah menentukan upaya yang tepat dalam membangun karakter pada anak usia prasekolah. Terdapat tiga unsur yang terkait, yaitu orang tua dalam lingkungan keluarga, guru dalam lingkungan sekolah, dan masyarakat termasuk teman sebaya. Ketiga unsur ini secara bahu membahu terus menyemaikan nilai-nilai, etika-moral, dan ajaran agama. Dengan kata lain upaya mengembangkan karakter menjadi tanggung jawab dan dapat dilakukan oleh keluarga, masyarakat, dan pemerintah. Proses pembangunan karakter pada anak diawali dengan pendekatan psikologis positif yang menggunakan asumsiasumsi, bahwa pada dasarnya setiap manusia memiliki keutamaan sebagai berikut: 
1. Cerdas dan baik, terhormat dan bermartabat. Asumsi ini menggambarkan kondisi psikis seseorang yang positif, memiliki potensi yang dapat dikembangkan secara optimal, dan memiliki daya tawar yang tinggi terhormat dan bermartabat sebagai mahluk yang mulia.

2. Dapat dipercaya dan bertanggung jawab, memiliki harapan dan cita-cita. Hal ini menggambarkan, bahwa pada dasarnya manusia bersifat amanah dan bertanggung jawab terhadap tugas-tugas yang diampunya serta memiliki harapandan cita-cita dalam hidupnya.

3. Bersedia secara sukarela dan dengan senang hati mengerahkan potensi terbaiknya apabila mendapatkan kesempatan. Asumsi ini menggambarkan manusia memiliki kesediaan untuk maju melalui pengembangan seluruh potensinya.

4. Bisa menentukan nasibnya sendiri, apabila menyadari jati diri dan potensi yang dimilikinya. Dengan kata lain, manusia mampu memilih dan menetukan pilihan masa depannya sendiri setelah menyadari mengenai jati diri dan potensinya.

Secara umum langkah-langkah yang dapat ditempuh oleh para orang tua dan guru secara bersama-bersama dalam membangun karakter kepada anak-anak, antara lain:

1. Membangun tata nilai sesuai dengan kearifan lokal dalam setiap lembaga dan masyarakat sebagai pedoman dalam berperilaku sendiri dan sedapat mungkin berlaku secara kolektif.
2. Nilai-nilai seperti integritas, dapat dipercaya, jujur, bertanggung jawab, berlaku hormat, adil, peduli dan sebagainya dapat digunakan sebagai salah satu rangsangan bagi pemilihan tata nilai yang sesuai bagi sutu institusi dengan artikulasi yang sesuai.

3. Mengkategorikan buku-buku bacaan, cerita-cerita, cerita rakyat, hikayat, serta permainan-permainan rakyat yang dapat dilakukan di lapangan terbuka, bahkan membuat film atau vedeoclips yang memuat nilai-nilai yang hendak ditanamkan kepada anak.

4. Melalui dialog-dialog atau tulisan-tulisan di media massa yang memuat informasi dan materi serta ajakan-ajakan untuk mendorong munculnya kesadaran berbagai lapisan masyarakat untuk menjadi suri teladan, amanah, dan tanggung jawab.

5. Mendorong para pendidik mulai dari Taman Kanak-Kanak sampai dengan Perguruan Tinggi, baik negeri maupun swasta untuk menjadi pelopor dalam membangun karakter bangsa.

6. Mendorong kembali munculnya kebiasaan ibu bercerita kapada anaknya (story telling) agar dapat membantu menanamkan nilainilai, etika-moral, kejujuran, dan karakter anak dengan menggambarkan secara operasional tentang kejujuran, tanggung jawab, santun, baik hati, dan rendah hati yang dicerminkan dalam kehidupan seharihari.

7. Mengembangkan penelitian yang berkaitan dengan nilai-nilai, moral, dan komponen utama karakter serta memahami ke- 
beragamannya dan kemudian membandingkannya untuk memperkaya pemahaman dan saling pengertian terhadap kondisi masyarakat yang majemuk dan kompleks.

Sementara itu, upaya-upaya untuk pembangunan karakter pada anak-anak memerlukan proses yang simultan dan berkesinambungan, sehingga keberhasilan yang dicapai dapat dijadikan dasar bagi pengembangan karakter yang lebih lanjut. Adapun aspek-aspek yang terlibat dalam proses membangun karakter anak menurut Ratna Megawangi (2008), meliputi: knowing the good, loving the good, and acting the good. Jika ketiga aspek ini dikaitkan dengan taksonomi Bloom, maka aspek knowing the good termasuk pada ranah kognitif, loving the good termasuk pada ranah afektif, dan aspek acting the good termasuk pada ranah psikomotor.

Implementasi pembangunan karakter anak dilakukan kepada seluruh dimensi manusia secara holistik. Dimensi-dimensi manusia tersebut, antara lain: dimensi spiritual, emosi, sosial, kreativitas, fisik, dan termasuk dimensi akademik baik dalam lingkungan rumah atau keluarga maupun sekolah dan masyarakat sekitarnya yang kondusif. Sementara itu, dalam membangun karakter pada anak dapat dilakukan dengan beberapa pendekatan, antara lain: knowing the good, reasoning the good, feeling the good, and acting the good.

Anak yang telah terbiasa dengan pendekatan knowing the good, reasoning the good, feeling the good, and acting the good dalam kehidupan sehari-hari lama kelamaan akan terbentuk karakternya sesuai dengan tujuan yang diharapkan oleh orang tua dan guru. Karakter yang melekat dalam diri anak dimanifestasikan dalam perilakunya yang mendapatkan bimbingan dari orang tua dan guru. Secara singkat pendekatan ini, antara lain:

1. Knowing the good. Ini merupakan salah satu pendekatan dalam pembinaan kepada anak agar berpikir yang baik-baik saja. Pendekatan ini berupaya membangun pikiran anak pada kebaikan. Orang tua dan guru menyampaikan pesan-pesan kebaikan berupa nilai-nilai, etika moral, ajaran agama dan keberanian menyampaikan kebenaran secara sistematis dengan menciptakan suasana yang kondusif.

2. Reasoning the good, merupakan pendekatan yang digunakan agar anak mengetahui mengapa harus berbuat baik. Mereka memahami alasan terhadap perbuatan baik yang dilakukannya. Misalnya mengapa harus berbuat jujur, dan apa akibat dari perbuatan jujur. Anak tidak hanya mengetahui tentang kebaikan, tetapi mengetahui alasan-alasan dari seluruh perbuatan baik yang dilakukannya.

3. Feeling the good, merupakan pendekatan untuk membangun perasaan anak terhadap kebaikan. Perasaan mereka disentuh dengan sebaik-baiknya untuk berbuat ke-baikan. Sehingga dengan pendekatan ini diharapkan agar anak mencintai kebaikan.

4. Acting the good, merupakan salah satu pendekatan yang digunakan oleh orang tua 
dan guru untuk mendorong anak mempraktikkan dan melaksanakan kebaikankebaikan yang disampaikan dan yang diperolehnya dari orang tua dan guru dalam kehidupan sehari-hari.

Pendekatan ini merupakan salah satu alternatif yang memiliki kelebihan dalam membangun karakter pada anak sesuai dengan harapan, tujuan orang tua dan guru, serta tahapan perkembangan anak. Orang tua guru bekerja sama menanamkan nilai-nilai, budaya, etika-moral, dan ajaran agama kepada anak melalui knowing the good, reasoning the good, feeling the good, and acting the good. Anak yang telah terbiasa dengan pendekatan ini kehidupan sehari-hari baik dalam lingkungan keluarga maupun lingkungan sekolah dan masyarakat lama kelamaan akan terbentuk karakternya sesuai dengan tujuan yang diharapkan dan ditentukan sebelumnya oleh orang tua dan guru. Karakter yang melekat dalam diri anak dimanifestasikan dalam perilakunya setelah mendapatkan arahan dan bimbingan dari orang tua dan guru.

\section{SIMPULAN}

Membangun karakter pada anak usia prasekolah merupakan proses penyemaian nilai-nilai, etika moral dan kejujuran yang yang terkandung dalam akhlak karimah dan dilakukan sejak anak secara dini. Nilai dasar yang paling utama disemaikan kepada anak usia prasekolah, meliputi: kejujuran, tanggung jawab, kebaikan hati, kemurahan hati, keteguhan hati, kebebasan, kesetaraan, dan sikap respek terhadap fenomena yang muncul di sekitar lingkungannya.

Terdapat dua sisi karakter yang melekat dalam diri individu, yaitu: pertama karakter pribadi merupakan akumulasi kebajikan yang mempengaruhi individu untuk melakukan yang benar, menyadari pentingnya moral, menjadi orang baik, etikal, tahu mana yang benar dan mana yang salah, bertindak konsisten sesuai Golden Rules. Kedua, Karakter kewarganegaraan, yaitu kebajikan pribadi dan nilainilai, seperti menghormati nilai dan otorita, bertanggung jawab, berperi laku dan berbuat adil, berkeadilan, dan berpartisipasi aktif dalam urusan-urusan kemasyarakatan.

Implementasi pembangunan karakter anak dilakukan kepada seluruh dimensi manusia secara holistik. Dimensi-dimensi manusia tersebut, antara lain: dimensi spiritual, emosi, social, kreativitas, fisik, dan termasuk dimensi akademik yang kondusif. Adapun dalam membangun karakter pada anak dapat dilakukan dengan pendekatan knowing the good, reasoning the good, feeling the good, and acting the good. Anak yang telah terbiasa dengan pendekatan-pendekatan ini dalam kehidupan sehari-harinya lama kelamaan akan terbentuk karakternya sesuai dengan tujuan dan harapan orang tua dan guru. Karakter yang melekat dalam diri anak dimanifestasikan dalam perilakunya yang mendapatkan bimbingan dari orang tua dan guru. 


\section{Daftar Pustaka}

Arifin, Bambang S.. (2008). Psikologi Agama. Bandung: Pustaka Setia.

Hendrojuwono, Wisnubrata. 2008. Menciptakan Lingkungan Transformasional Demi Membangun Karakter Bangsa. Bandung: IPPI.

Mahfuzh, Jamaluddin M.. (2001). Psikologi Anak dan Remaja Muslim. Jakarta: Pustaka Al-Kautsar.

Megawangi, Ratna. (2008). Pendidikan Karakter pada Anak Usia Dini sebagai Pembangunan Sumber Daya Manusia. Bandung: IPPI.

Wynne, E. A. (1991). Character and Academics in the Elementary School. In J.S. Beninga (Ed). Moral, character, and Civic Education in the Elemantary School. New York: Teacher College Press. 